\title{
Microbial Evaluation of Groundwater and its Implications on Redox Condition of a Multi-Layer Sedimentary Aquifer System
}

\author{
Tirumalesh Keesari • K. L. Ramakumar • \\ M. Bala Krishna Prasad • S. Chidambaram • \\ Petha Perumal • D. Prakash • N. Nawani
}

Received: 17 October 2014 / Accepted: 23 February 2015 / Published online: 19 March 2015

(C) Springer International Publishing Switzerland 2015

\begin{abstract}
A synoptic microbial assessment of groundwater has been carried to describe the groundwater quality and its geochemical environment in the Pondicherry region located in the southeast part of India. Spatial and vertical variability in dissolved oxygen (DO) and chemical species clearly explain that regional geological settings associated with human pressure are controlling the groundwater quality in this region. Results show that the abundance of bacteria is positively related to DO, total organic carbon (TOC) and inversely related to well depth, whereas sulphate reducing bacteria (SRB) present at some locations do not show any systematic trend with the above parameters. About half of the measured groundwater samples showed presence of $E$. coli. Some suboxic deep aquifers $(\mathrm{DO} \leq 2 \mathrm{mg} / \mathrm{L})$ showed presence of E.coli which are not commonly observed. SRB are found mostly in deeper Tertiary and Cretaceous aquifers reflecting presence of reducing conditions. The rapid accumulation of organic matter associated with heterotrophic conditions has increased the prevalence of redox sensitive SRB in coastal zones of Pondicherry region. Reducing conditions in deeper aquifers of Cretaceous and Tertiary formations and availability of Marcasite in these formations may lead to possible arsenic contamination in groundwater. Climate change induced sea level rise
\end{abstract}

T. Keesari $\cdot$ K. L. Ramakumar

Bhabha Atomic Research Centre, Mumbai 400085, India

M. B. K. Prasad $(\bowtie)$

22616 Shining Harness Street, Clarksburg, MD 20871, USA

e-mail: mbkprasad@gmail.com

S. Chidambaram

Earth Sciences Department, Annamalai University, Annamalai Nagar 608002 Tamil Nadu, India

P. Perumal

Agricultural Department, Pondicherry 673 310, India

D. Prakash

Department of Microbiology, University of Pune, Pune 411007 Maharashtra, India

N. Nawani

Dr. D. Y. Patil Biotechnology and Bioinformatics Institute, Pune 411033 Maharashtra, India 
and human pollution may exacerbate the nutrient and microbial pollution in this coastal region, and this warrants a detailed investigation so that proper protection strategies for sustainable management of the groundwater resources along the Indian coastal zone can be proposed.

Keywords Microbial contamination - Dissolved oxygen - Sulphate reducing bacteria . Groundwater P Pondicherry

\section{Introduction}

Groundwater investigations have mainly focused on supplies with little emphasis given to its microbial quality. In the past, the assumption prevailed that much of the bacteria that contaminated surface water could be absorbed or retained by soils through filtration and leave groundwater free from contamination. This notion has been refuted by continuing outbreaks of waterborne diseases in India and abroad (e.g., Vignesh et al. 2015; Paruch et al. 2014; Anderson and Bohan 2001; Craun et al. 1997; Pathak et al. 1991; Vaidya et al. 2001; Walsh 1990).

Groundwater contains different types of micro-organisms, including viruses, bacteria and parasites. Fecal pollution of waters is of special concern since the most important bacterial gastrointestinal infections in humans, viz., cholera, salmonellosis and shigellosis, are primarily transmitted by water polluted with feces of infected persons (Grabow 1996; Scott et al. 2003). The most important aspect of water quality is its lack from contamination with fecal matter. The higher the level of fecal contamination, the greater is the risk of water-borne diseases (Pipes 1981). Microbiological assessment of the groundwater can significantly contribute to identify microbial contamination of the water, so that potential danger of health risks can be averted by taking proper remedial actions such as water treatment and decontamination (Stein et al. 2010). Besides addressing water quality issues, microbial evaluation of groundwater is also crucial in understanding the geochemical behavior of the aquifer. In recent times, it is becoming increasingly evident that microbial evaluation plays a significant role in characterizing the inorganic processes affecting the leaching and transport of toxic elements in deeper subsurface horizons (Hesham et al. 2009; Mohamed and Sonja 2008). Proper evaluation of the microorganisms is also important for any geochemical modeling (Lotta and Karsten 2008) to address the fate of pollutants.

In India, despite several laws and regulations endorsed by agencies like Environmental Protection Agency, Central \& State Groundwater Boards and the Pollution Control Boards, sewer outflows and discharges of the partially treated and untreated wastewater from septic systems and storm water runoff from urban and rural areas are still major sources of pollution of drinking waters. Investigations carried out in some parts of the country pointed out contamination by fecal matter (Kumar and Dube 1985; Mohan et al. 2000; Venkateswaran and Natarajan 1987). According to a report by Planning Commission, India (2002), the risk of water contamination resulting in water-borne disease is higher in rural areas due to illmaintained water pipelines and sewer lines, lack of disposal of human, animal and household wastes, and lack of awareness of good sanitation and personal hygienic practices. Statistics show that the poor sanitation and hygiene practices in India have led to increased diarrheal problems in the order of 22 million annually (Shankar et al. 2011). Like many other coastal urban regions, Pondicherry has undergone rapid growth in the last few decades and is endowed with substantial water resources due to a wide network of ponds and two rivers (Gingee and Pennaiyar) that flow into the Bay of Bengal through this region. About $90 \%$ of the Pondicherry region comprises alluvial aquifers with fairly good water quality and shallow water levels in the wells ranging between 12 and $14 \mathrm{~m}$ below ground level (bgl). Agriculture is 
the dominant land-use and groundwater contributes $80 \%$ of water requirement. The groundwater exploitation has been increased exponentially in the recent years to meet increased population demands (Thangarajan and Thyagarajan 2003), which has resulted in a substantial decline in groundwater table over the last decade in the range of 15 to $30 \mathrm{~m}$ in the west and about $7 \mathrm{~m}$ in the eastern part of Pondicherry (D'ozouville et al. 2006).

Recent reports suggest that global warming has resulted in extreme climate events, which coupled with sea level rise synergistically will influence the quantity and quality of both surface and sub-surface water in coming years. Climate change induced global sea level rise is projected to increase from 9 to $88 \mathrm{~cm}$ (Church 2001) and 50 to $140 \mathrm{~cm}$ (Rahmstorf 2007) by 2100 under a wide variety of greenhouse gas scenarios. Similarly, insitu and remote sensing analyses exemplify that anthropogenic warming increase sea level rise along the Indian coast (Han et al. 2010), at the rate of $1.06-1.75 \mathrm{~mm} /$ year (Unnikrishnan and Shankar 2007). It is also projected that human population density along the coastal zone will be increased by $\sim 50 \%$ by the end of 21 st century and indeed degrade both the surface and sub-surface water by high nutrient loads (NRC 2000). The regional ecological models predict that terrestrial nutrient inputs will be increased by several folds over the next several years due to drastic changes in land-use (Foley et al. 2005) and will have remarkable effects on the coastal water quality (Seitzinger et al. 2010). Similar observations were also noticed in the study area. Climate change induced sea level rise and salt water intrusion have also significantly impacted the groundwater quality in coastal Pondicherry region (Gilles 2005). Increasing human pressure alters the hydro-chemical and microbial properties of water, which in turn can be used to determine the impact of anthropogenic activities on the groundwater systems in the Pondicherry region. Hence, an integrated hydrochemical and microbial assessment of groundwater has been carried out to evaluate the microbial quality and the possible sources in different aquifers of coastal Pondicherry region.

The coliform bacteria (Escherichia coli, E. coli) were enumerated for the assessment of the fecal contamination of groundwater from three major aquifers of the region viz., Quaternary Alluvium, Tertiary and Cretaceous sedimentary formations in the Pondicherry region. In addition, an assay of total microbial loads (total viable counts- TVC) in different aquifers, distribution of E. coli and TVC laterally and vertically, correlations with dissolved oxygen, total organic carbon were also carried out. An attempt was also made to characterize the geochemical condition of the deeper aquifers of this region using sulphate reducing bacteria (SRB). The hydrochemical and microbial data from this study would be highly useful to evaluate the anthropogenic perturbations on the regional water resources that would further facilitate planning of various schemes for better management and restoration of groundwater systems in coastal parts of India.

\section{Study Area}

The Pondicherry Region is located on the east coast of India forming enclaves within the Cuddalore District of Tamil Nadu. It is bounded by north latitudes $11^{\circ} 45^{\prime}$ and $12^{\circ} 03^{\prime}$ and east longitudes $79^{\circ} 37^{\prime}$ and $79^{\circ} 53^{\prime}$ (Fig. 1). The Bay of Bengal forms the eastern boundary of this region and, on the remaining sides, it is covered by lands of Cuddalore district. The region is divided into seven communes for administrative convenience, where a commune is the smallest administrative unit. The total area of this region is $293 \mathrm{~km}^{2}$ and comprises 179 villages. Agriculture, vegetation and plantation together cover $\sim 76 \%$ of the total area, followed by settlement areas $(\sim 15 \%)$, water bodies $(\sim 7.5 \%)$, and the remaining part is barren 


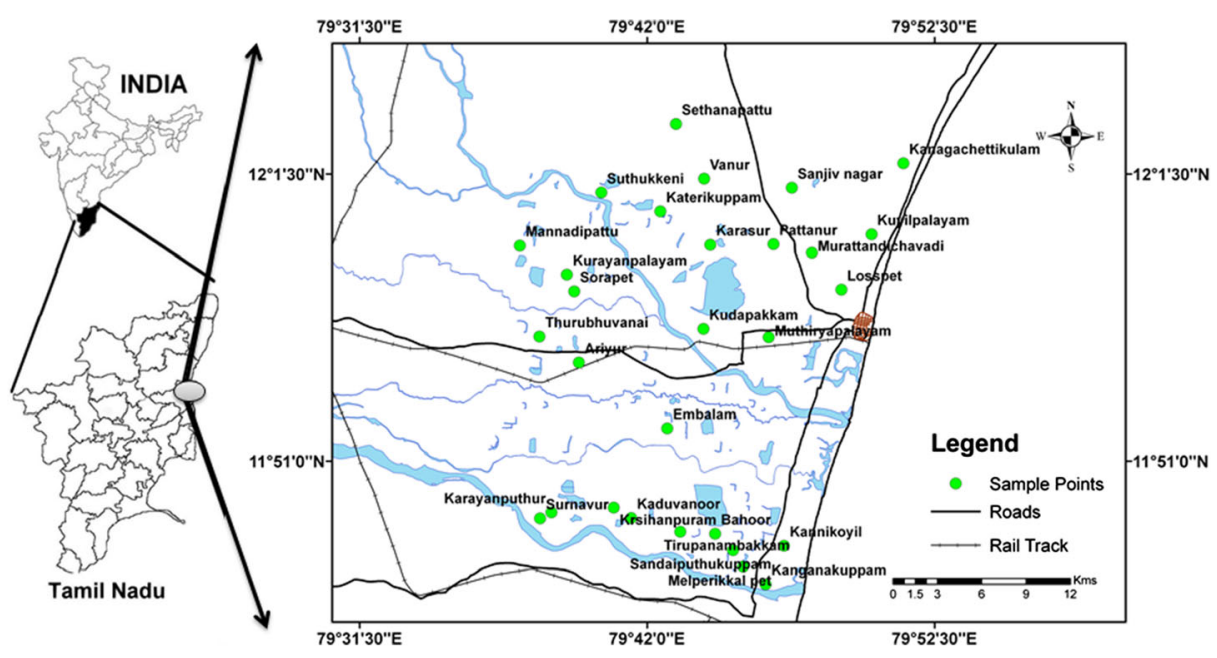

Fig. 1 Location of the study area with sampling points

land $(\sim 1.5 \%)$. Industrial units are concentrated in and around Mettupalayam and Keerumampakkam areas. Due to lack of proper maintenance of irrigation tanks in Pondicherry region the entire load of irrigation relies on groundwater resources. Apart from this, the requirement of drinking water and industries is also being met by the groundwater resources.

This region is mostly covered by sedimentary formations ranging in age from Cretaceous to Recent. Among the seven different sedimentary formations in this region, three formations are found to be potential in terms of groundwater development, viz., Alluvium (Quaternary), Cuddalore sandstone (Tertiary) and Vanur-Ramanathapuram sandstone (Cretaceous). Quaternary formations in the region are represented by laterites and alluvium (CGWB 1993). Laterite occurs as thin cap over these formations. The thickness of the aquifer ranges between 5 and $34 \mathrm{~m}$. Groundwater in this aquifer occurs under un-confined to semi-confined condition. The depth of wells tapping this aquifer ranges between 25 and $50 \mathrm{~m} \mathrm{bgl}$. Tertiary formations are predominantly calcareous sandstones, yellowish grey to dirty white in color, with thin lenses of clay and shale and bands of shell limestone. Thin seams of lignite also occur in these formations (CGWB 1993; Sukhija et al. 1987). Groundwater occurs mainly under confined condition and the piezometric levels range between 10 and $25 \mathrm{~m} \mathrm{bgl}$. Cretaceous formations comprise alternate layers of grey sandstone and carbonaceous-clay stone with thin seams of lignite and abundant marcassites. Groundwater in these formations occurs under confined conditions and the piezometric head at present is about 20 to $60 \mathrm{~m} \mathrm{bgl}$.

The topography of the area is a flat plain with an average elevation of about $15 \mathrm{~m}$ above mean sea level (amsl). The climate of Pondicherry region is humid and tropical. The mean monthly temperature ranges between 22 and $33{ }^{\circ} \mathrm{C}$. The relative humidity varies between 70 and $80 \%$ and is highest during December - January and lowest during June. The average annual rainfall in Pondicherry is $1254 \mathrm{~mm}$. The region receives rainfall from monsoons spreading over a period of 7-8 months. The southwest monsoon brings $29 \%$ of the annual rainfall from June to September and the North East Monsoon brings $63 \%$ from October to December. 


\section{Sampling and Measurement}

Water sampling was carried out during post monsoon period of 2009 from 29 wells tapping different depths from 10 to $185 \mathrm{~m} \mathrm{bgl}$ and covering major aquifers. Prior to collection of samples, wells were purged until constant temperature was obtained. The water sample for microbiological analyses was collected in a sterile glass bottle, kept in airtight ice-cold containers and transported to laboratory within $6-8 \mathrm{~h}$ of their collection for further processing. For determination of reducing bacteria, sample bottles were flushed with nitrogen and sealed using Teflon to prevent contact with atmospheric oxygen. Acid-washed polyethylene containers were used for total organic carbon analysis. The location of the sampling sites is shown in Fig. 1.

\subsection{Physical Parameters and Total Organic Carbon (TOC)}

Physical parameters, like temperature, $\mathrm{pH}$ and $\mathrm{DO}$, were measured in situ using portable $\mathrm{pH} /$ Temp - DO meter (Corning, model 313) with a precision of \pm 0.02 units and $\pm 0.1 \%$ for $\mathrm{pH}$ and DO, respectively. Total Dissolved Solids (TDS) measurements in $\mathrm{mg} / \mathrm{L}$ were calculated by multiplying a factor 0.64 with electrical conductivity obtained from conductivity meter (Orion model 130) with a precision of $\pm 0.5 \%$. Alkalinity was measured in the field by titration of $10 \mathrm{~mL}$ of water sample with $0.02 \mathrm{~N} \mathrm{H}_{2} \mathrm{SO}_{4}$. A mixed indicator (Bromocresol green - Methyl red) was used to mark the end point of the reaction at $\mathrm{pH} 4.3$. For total organic carbon measurements samples were acidified with $\mathrm{HCl}$ to a $\mathrm{pH}$ value of 3 immediately upon collection and stored at $4{ }^{\circ} \mathrm{C}$ in the dark until analysis. The measurements were performed with a SGE TOC analyzer (ANATOC II series). This is a closed loop technique and works on the principle of photo catalytic oxidation process occurring at room temperature in near UV region at $400 \mathrm{~nm}$ using atmospheric oxygen. The catalyst used is $\mathrm{TiO}_{2}$ in the form of a packed column. The carbon dioxide thus formed is measured by non-dispersive infrared detection. The precision and the detection limit of the measurement were $\pm 2 \%$ and $0.025 \mathrm{mg} / \mathrm{L}$, respectively.

\subsection{Microbial Assays}

\subsubsection{Total Viable Bacteria (TVB)}

The enumeration of microbial populations was accomplished by using the Total Viable Count (TVC) method. TVC was performed on a nutrient agar media by means of spread plate method. Dilution of the sample was made in the order of $10^{-3}$ and $10^{-4}$ using sterile saline, and one milliliter of diluted sample was transferred in to petriplates containing a molten agar medium $\left(45^{\circ} \mathrm{C}\right)$. The plates were incubated at $37^{\circ} \mathrm{C}$ for $24 \mathrm{~h}$ to obtain viable colonies. Each test was duplicated and comparable results were averaged to reduce any errors related to the measurement. The viable colonies were counted and converted to represent colony forming units per $\mathrm{mL}(\mathrm{CFU} / \mathrm{mL})$. A typical plate of bacterial colonies is shown in Fig. 2a.

\subsubsection{Escherichia coli (E.coli)}

A media containing violet red blue bile agar (VRBA) was used to detect the coliforms. One $\mathrm{mL}$ aliquot of undiluted sample was transferred on VRBA by pour plate method and incubated at $35{ }^{\circ} \mathrm{C}$ for $24 \mathrm{~h}$. The positive colonies (purple red colonies with diameter $0.5 \mathrm{~mm}$ or more) were counted and expressed as CFU 100/mL. Figure 2b shows the presence of E.coli bacteria by characteristic purple colonies. The presence of $E$. coli was confirmed with an indole test. 

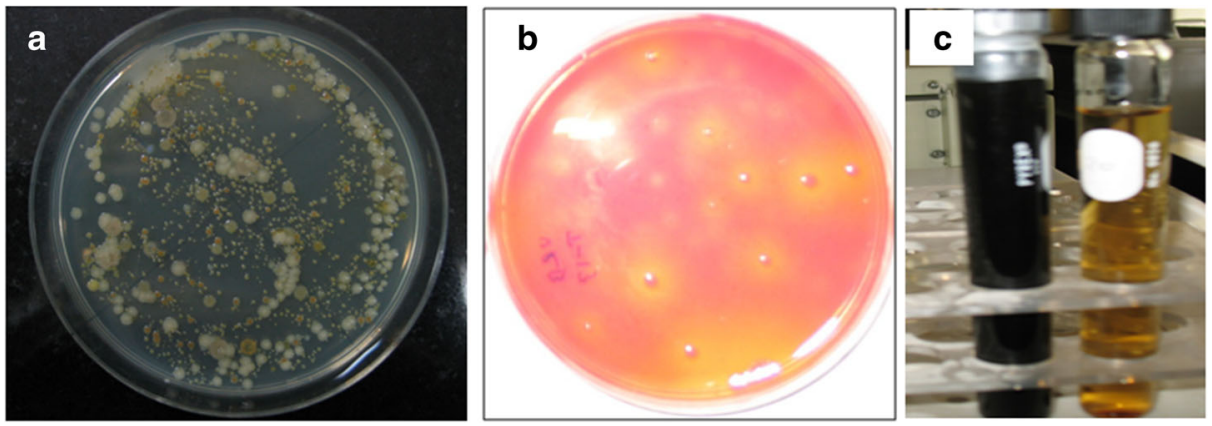

Fig. 2 Colony plates showing: a the diverse nature of bacterial communities; $\mathbf{b}$ E. coli with characteristic purple colored colonies; and $\mathbf{c}$ black coloration of FeS indicating presence of sulphate reducing bacteria

\subsubsection{Sulphate Reducing Bacteria (SRB)}

Sulphate reducing bacteria were grown in long necked bottles with the medium composition of tryptone $(30 \mathrm{~g})$, sodium sulphate $(5 \mathrm{~g})$, sodium sulphite $(5 \mathrm{~g})$ and ferric citrate $(2 \mathrm{~g})$ in $1 \mathrm{~L}$ distilled water (Ministry of Health 1939). The growth of a sulphate reducer is recognized by the appearance of the black color of ferrous sulphide (Fig. 2c). The medium used for the enumeration of SRB is prepared with the following composition: Yeast Extract (1), Ascorbic acid $(1 \mathrm{~g} / \mathrm{L}), \mathrm{MgSO}_{4}(0.2 \mathrm{~g} / \mathrm{L}), \mathrm{K}_{2} \mathrm{HPO}_{4}(0.01 \mathrm{~g} / \mathrm{L})$, Ferrous Ammonium Sulphate $(0.1 \mathrm{~g} / \mathrm{L})$, $\mathrm{NaCl}(10 \mathrm{~g} / \mathrm{L})$, Agar-agar $(25 \mathrm{~g} / \mathrm{L})$, Sodium Lactate $(4 \mathrm{~g} / \mathrm{L})$. The $\mathrm{pH}$ of the medium was maintained at 7.0 by $1 \mathrm{~N} \mathrm{NaOH}$. The above medium was autoclaved at $15 \mathrm{lbs}$ for $15 \mathrm{~min}$. The medium was cooled to $40{ }^{\circ} \mathrm{C}$ and the samples were diluted ten times. Pour plate method was employed and the plates were allowed to solidify. Once the medium was set, the plates were stacked in an anaerobic jar and the jar was subjected to vacuum to remove the residual oxygen $(-15 \mathrm{lbs})$. The jar was then filled with a mixture of gases $\left(10 \% \mathrm{CO}_{2}, 5 \% \mathrm{O}_{2}\right.$ and $\left.85 \% \mathrm{~N}_{2}\right)$ till the gauge read zero. The jar was then incubated at $37{ }^{\circ} \mathrm{C}$ for 5 days. Black colonies displaying sulphur reduction were further subcultured on the medium mentioned above in slants and incubated in a similar manner. Plates where the count was prevalent but did not exhibit any black colonies were not considered.

\section{Results}

\subsection{Chemistry of Groundwater}

Physicochemical parameters along with microbiological data are given in Table 1. $\mathrm{pH}$ varied from 6.0 to 8.8 and most of the samples showed $\mathrm{pH}$ values within allowed limits of 6.5 to 8.5 (BIS 1995). A spatial variation map of $\mathrm{pH}$ is shown by Fig. 3a. Alkaline $\mathrm{pH}$ is observed in two samples ( $\sim \mathrm{pH} 8.8$ ) that are collected from shallow wells (depth $\sim 15 \mathrm{~m} \mathrm{bgl}$ ); this high $\mathrm{pH}$ could be due to man-made activities. In contrast, a few deep zone samples show slightly acidic nature of water $(\mathrm{pH}$ 6.0-6.5). This acidic nature of water can result from subsurface chemical processes like oxidation of sulphide minerals or biological processes. The mineralization of the groundwater is generally represented by TDS. From Table 1, it is noticed that groundwater quality is good as the TDS values fall between 160 and $1000 \mathrm{mg} / \mathrm{L}$ and are within drinking water limits set by Bureau of Indian Standards (BIS 1995). There are two deep wells (depths 
Table 1 Microbiological data of groundwater from Pondicherry area along with physical parameters and geological formation

\begin{tabular}{|c|c|c|c|c|c|c|c|c|c|c|}
\hline Location & Well Depth & Temp. & $\mathrm{pH}$ & $\mathrm{DO}$ & TDS & TOC & TVC & E.coli & SRB & Formation \\
\hline Ariyur & 18 & 30.9 & 7.36 & 4.0 & 1100 & 1.62 & 3650 & 300 & nd & Quaternary \\
\hline Bahoor & 180 & 31.7 & 6.66 & 1.9 & 401 & bdl & 3760 & nd & 560 & Tertiary \\
\hline Embalam & 10 & 31.6 & 7.41 & 5.1 & 669 & 1.20 & 33000 & 110 & nd & Quaternary \\
\hline Kaduvanoor & 50 & 30.4 & 8.12 & 4.9 & 993 & 0.62 & 18000 & 15 & nd & Quaternary \\
\hline Kanagachettikulam & 91 & 31.1 & 7.31 & 2.2 & 1108 & bdl & 4300 & 25 & nd & Cretaceous \\
\hline Kanganakuppam & 140 & 32.9 & 6.32 & 2.0 & 230 & bdl & 1800 & 20 & nd & Tertiary \\
\hline Kannikoyil & 180 & 32.3 & 6.27 & 1.6 & 257 & bdl & 10800 & nd & nd & Tertiary \\
\hline Karasur & 185 & 32.1 & 6.87 & 2.5 & 1404 & 1.31 & 4500 & 30 & 2300 & Cretaceous \\
\hline Karayanputhur & 15 & 31.2 & 8.83 & 4.6 & 553 & 0.38 & 3100 & 60 & nd & Quaternary \\
\hline Katerikuppam & 180 & 30.5 & 7.05 & 2.5 & 449 & 0.56 & 17600 & nd & 610 & Cretaceous \\
\hline Krsihanpuram & 71 & 31.2 & 7.20 & 2.6 & 767 & bdl & 4800 & nd & 250 & Tertiary \\
\hline Kudapakkam & 13 & 31.4 & 8.30 & 5.4 & 488 & 1.37 & 22000 & nd & nd & Quaternary \\
\hline Kurayanpalayam & 91 & 31.4 & 7.22 & 2.0 & 797 & 1.25 & 2800 & 5 & 3100 & Cretaceous \\
\hline Kuyilpalayam & 37 & 31.5 & 6.02 & 2.8 & 180 & bdl & 8000 & nd & 360 & Tertiary \\
\hline Losspet & 100 & 31.1 & 6.35 & 5.0 & 694 & bdl & 9100 & nd & nd & Tertiary \\
\hline Mannadipattu & 10 & 31.7 & 7.97 & 5.8 & 438 & 1.03 & 18000 & nd & nd & Quaternary \\
\hline Melperikkal pet & 20 & 31.1 & 8.48 & 4.2 & 1235 & 1.89 & 3600 & 300 & nd & Quaternary \\
\hline Murattandichavadi & 80 & 32.1 & 6.73 & 3.5 & 164 & bdl & 4500 & 15 & nd & Tertiary \\
\hline Muthiryapalayam & 95 & 31.0 & 6.59 & 1.0 & 472 & 1.73 & 3950 & 180 & nd & Tertiary \\
\hline Pattanur & 24 & 30.9 & 7.24 & 3.7 & 736 & 3.24 & 18800 & nd & nd & Tertiary \\
\hline Sandaiputhukuppam & 16 & 31.1 & 7.65 & 4.3 & 767 & 0.15 & 4000 & 50 & nd & Quaternary \\
\hline Sanjivnagar & 152 & 32.5 & 7.31 & 2.3 & 852 & bdl & 8000 & nd & nd & Cretaceous \\
\hline Sethanapattu & 100 & 31.6 & 7.32 & 2.2 & 794 & 0.83 & 24600 & 10 & 580 & Cretaceous \\
\hline Sorapet & 13 & 31.5 & 8.80 & 4.9 & 590 & 0.22 & 21600 & 10 & nd & Quaternary \\
\hline Surnavur & 61 & 29.5 & 7.30 & 5.5 & 511 & bdl & 25400 & 75 & nd & Tertiary \\
\hline Suthukkeni & 120 & 30.8 & 7.87 & 4.8 & 325 & 0.73 & 2700 & nd & nd & Quaternary \\
\hline Thurubhuvanai & 20 & 31.2 & 8.19 & 5.3 & 662 & 0.86 & 2400 & nd & nd & Quaternary \\
\hline Tirupanambakkam & 120 & 30.8 & 7.12 & 2.6 & 460 & bdl & 5600 & 50 & 1100 & Tertiary \\
\hline Vanur & 180 & 31.1 & 7.34 & 4.0 & 625 & 2.05 & 30000 & nd & 260 & Cretaceous \\
\hline
\end{tabular}

$n d$ not detected, $b d l$ below detection limits, well depth (m bgl), Temp. $\left({ }^{\circ} \mathrm{C}\right)$, DO, TDS, TOC (mg /L), TVC, SRB (CFU/mL), E. coli (CFU/100 mL)

90 and $185 \mathrm{~m} \mathrm{bgl}$ ) and one shallow well (depth $20 \mathrm{~m} \mathrm{bgl}$ ) showing TDS values more than $1000 \mathrm{mg} / \mathrm{L}$. This may be possibly due to leaching of salts from the formation in the case of deep wells and influence of lagoon water in the shallow well. From the spatial distribution of TDS (Fig. 3b), it can be observed that there is no systematic increase in TDS towards the seaside, indicating absence of seawater intrusion in these locations.

The dissolved oxygen concentration in water at equilibrium with air at $25{ }^{\circ} \mathrm{C}$ at $1 \mathrm{~atm}$ is $8.3 \mathrm{mg} / \mathrm{L}$ (Fifield and Haines 2000). Generally, in alluvial shallow groundwaters, the DO values are close to $8.3 \mathrm{mg} / \mathrm{L}$. However, several biological and inorganic processes taking place in the subsurface may consume dissolved oxygen and deplete the DO levels. The water samples collected in the study area had DO between 1 and $6 \mathrm{mg} / \mathrm{L}$ and a spatial variation is 

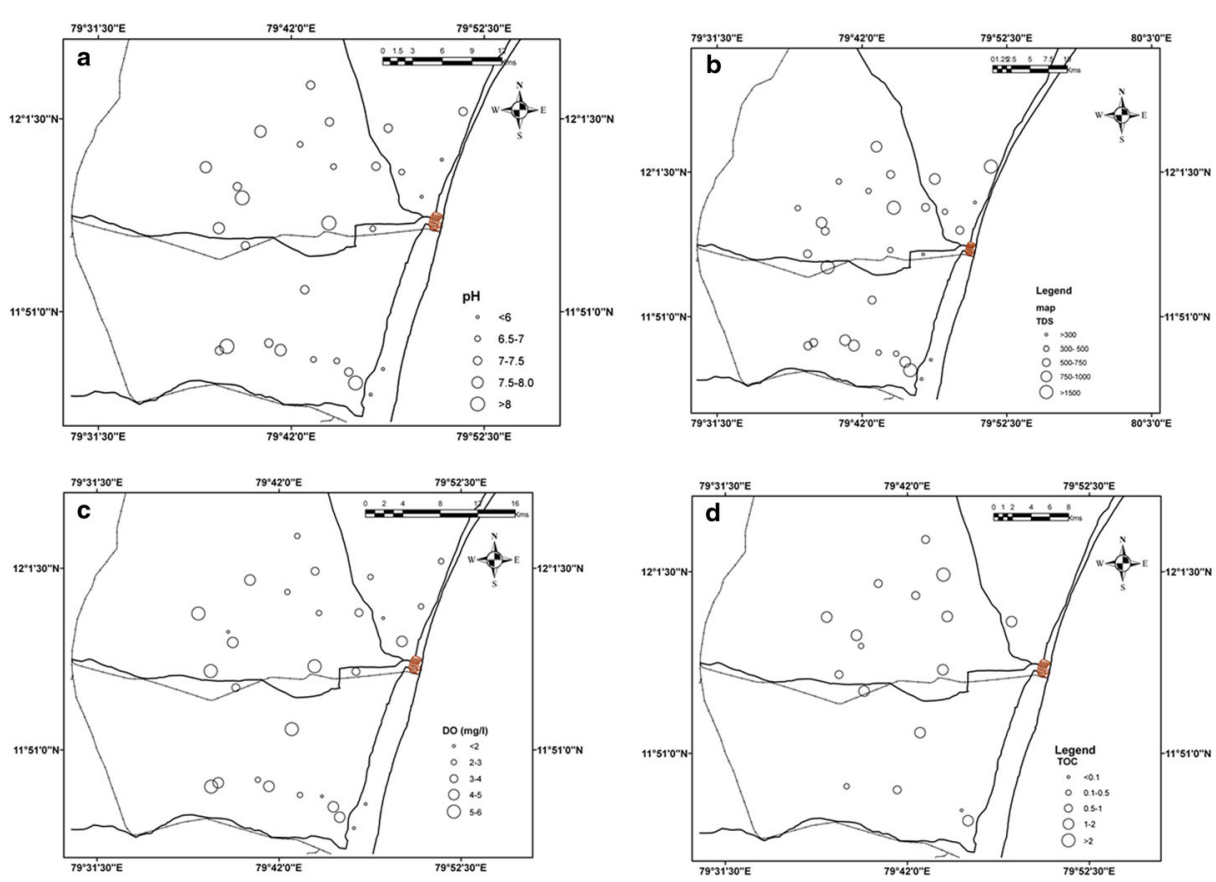

Fig. 3 Spatial distribution of: a pH; b TDS (mg/L); c Dissolved Oxygen (mg/L); and d total organic carbon (mg/L)

shown in Fig. 3c. It is surprising to note that even alluvial shallow wells that are supposingly at equilibrium with atmosphere contain DO levels between 3 and $6 \mathrm{mg} / \mathrm{L}$. This lowering of DO can be attributed to the presence of ferruginous / lateritic soils in this region that consume oxygen during the conversion of ferrous to ferric ion. The equilibrium reaction can be represented by the following equation:

$$
\mathrm{Fe}^{2+}+1 / 2 \mathrm{O}_{2}+\mathrm{H}^{+} \leftrightarrow \mathrm{Fe}^{3+}+1 / 2 \mathrm{H}_{2} \mathrm{O}
$$

Deep wells show depleted DO levels, which can be attributed to heterotrophic biological respiration. This depletion coincides with the high TOC concentrations in groundwater. Most of the groundwater tapping deep waters have DO levels close to $2.0 \mathrm{mg} / \mathrm{L}$ and can be considered to be under sub-oxic condition (Tyson and Pearson 1991). Although $\mathrm{H}_{2} \mathrm{~S}$ gas odor was very prominently felt during the field sampling, none of the samples showed complete depletion of DO (i.e., DO of $0 \mathrm{mg} / \mathrm{L}$ ). This might be mostly due to contribution of water from the shallow zone through vertical leakage. Since these formations shows presence of Lignite lenses and Marcasite in the study area, it can be presumed that deposition of the sediments occurred during reducing condition (CGWB 1993). Stratigraphic studies also point to reducing condition of the sedimentary formation (Kennedy and Henderson 1992; Sundaram et al. 2001).

Organic carbon is generally used as an indicator of susceptibility of groundwater for bacterial contamination since it serves as a nutrient source for microbes (Katzenelson 1978). Organic substances originating either from the active soil zone or from the aquifer material dissolve in groundwater and lead to growth of fungi and algae. This is not a desired condition for groundwater being used for drinking. The organic substances generally include humic acids, hydrocarbons, fatty acids, etc. The dissolved organic matter is also contributed by the anthropogenic activities such as petroleum products or organic industrial wastes. All the well waters show TOC levels 
between 0.1 to $3.2 \mathrm{mg} / \mathrm{L}$ and relatively higher levels are observed in shallow wells. A general trend of TOC is shown in Fig. 3d. The low amounts indicate either absence of anthropogenic inputs to the groundwater system or consumption of the organic matter by microbes.

\subsection{Microbes in Groundwater}

The standard plate count (TVC) in the groundwater was in the range between $1.8 \times 10^{3}$ and $3.3 \times 10^{4} \mathrm{CFU} / \mathrm{mL}$ in different aquifers. The colonies were identified on the basis of their cultural characteristics on agar plates and microscopic observations. Five to ten different varieties of microbial communities with different morphology and strains of bacteria were observed. The distribution of TVC varied greatly among different wells, shown in Fig. 4a, which can be attributed to factors like chemical characteristics of the catchment area, extent and range of human activities and animal sources in the vicinity of the wells.

About half of the samples (16 out of 29) measured showed presence of E. coli, and four samples showed high values between 100 and $300 \mathrm{CFU} / 100 \mathrm{~mL}$, i.e., they were severely contaminated. The limits set by Bureau of Indian Standards (BIS 1995) and World Health Organizations (WHO 2004) are given in Table 2. According to the WHO guidelines for drinking water quality there should be no trace of total or fecal coliforms present in $100 \mathrm{~mL}$ of water. Therefore, half of the groundwater samples measured can be considered as unfit for drinking. Spatial distribution of E. coli in the study area is shown in Fig. 4b. The presence of $E$. coli can be attributed to pollution sources such as waste dumps and sewages.

Some samples (9 out of 29) showed the presence of SRB in the range of 250-3100 CFU/mL. It was observed that these samples were mostly collected from wells tapping deeper horizons $(>100 \mathrm{~m} \mathrm{bgl})$ with low DO levels. The presence of SRB indicates that groundwater is under low oxic or reducing condition in these locations. A spatial distribution map of SRB is shown in Fig. 4c. No sample from Quaternary alluvium showed the presence of SRB. All the samples tested positive for SRB belong to either Tertiary or Cretaceous sedimentary aquifers. Variation of SRB can be due to varying amounts of organic matter, dissolved sulphate and other sediment properties (Kirsten and Donald 1997; Westrich and Berner 1984). In marine sediments, organic acids derived primarily from fermentation serve as the SRB's main carbon sources (Tranvik 1992). These deeper formations (Cretaceous and Tertiary) were formed under marine influence (CGWB 1993; Kennedy and Henderson 1992; Sundaram et al. 2001), therefore, it is possible that the sediments may contain organic matter and could serve as energy sources for SRB.

\section{Discussion}

Increasing population density coupled with inadequate sewage treatment and disposal facilities in the urban parts of Pondicherry have put groundwaters of this region in a vulnerable position with respect to microbial contamination. On the other hand, improper management of tanks, unplanned dumping of agricultural and domestic wastes, lack of awareness of good sanitation and personal hygienic practices in the rural areas of this region made groundwater resources susceptible to microbial pathogens. Communicable diseases such as typhoid, paratyphoid, amoebic dysentery, bacillary dysentery, cholera and infective hepatitis were noticed in this region which can be attributed to fecal contamination of potable water. A wide range of pathogenic microorganisms can be transmitted via fecal contamination that include enteropathogenic agents (salmonellas, shigellas, enteroviruses, and multicellular parasites) as well as pathogens such as Pseudomonas aeroginosa, Klebsiella, Vibrio parahaemolyticus and 

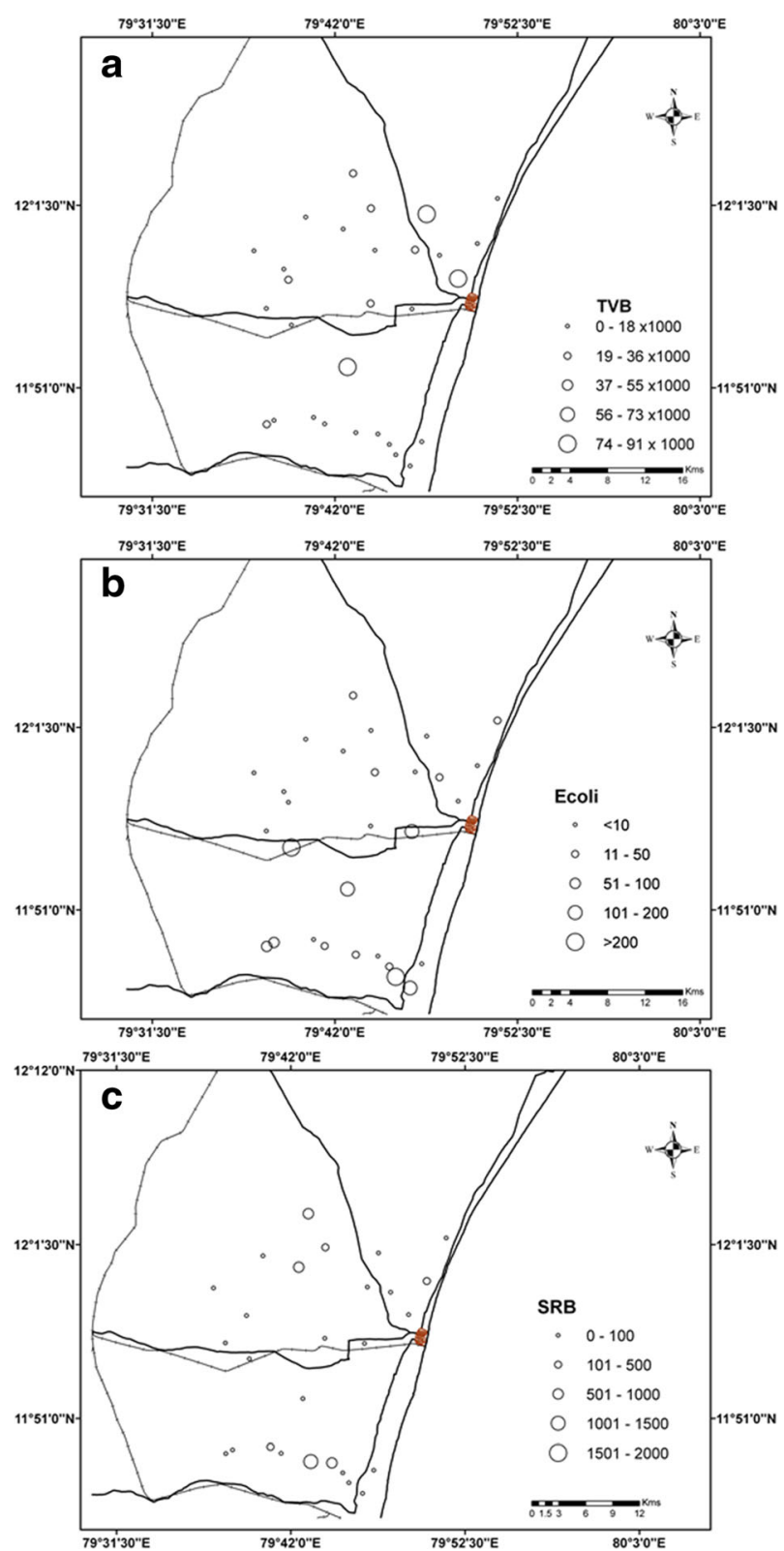

Fig. 4 Spatial distribution of: a TVB (CFU/mL); b E. coli (CFU/100 mL); and c SRB (CFU/mL)

Aeromonashydrophila (Hodegkiss 1988). The abundance and diversity of microorganisms are useful to evaluate the suitability of water for drinking purposes (Okpokwasili and Akujobi 1996). However, it is not practicable to test water for all these organisms as the isolation and identification of many of these organisms are extremely complicated (Cairneross et al. 1980). An indirect approach is to assess the coliform bacteria, which are most widely used as indicators of fecal contamination (Kistemann et al. 2002; Pathak and Gopal 2001; Vaidya 
Table 2 Contamination status of drinking water on the basis of E. coli

\begin{tabular}{lll}
\hline E. coli CFU/L & Water pollution status-WHO 2004 & Water pollution status-BIS 1995 \\
\hline 10,000 & Heavily polluted & Polluted \\
1000 & Polluted & Polluted \\
100 & Slightly polluted & Polluted \\
10 & Satisfactory & Acceptable \\
3 or less & Potable & Excellent
\end{tabular}

et al. 2001). Thus, the presence of Escherichia coli in water provides evidence of excreta of fecal pollution of human or animal origin.

In the study area, it is found that the non-disinfected groundwater has high bacterial loads (TVC: $1.8 \times 10^{3}$ to $3.3 \times 10^{4} \mathrm{CFU} / \mathrm{mL}$ ) and presence of $E$. coli in half of the analyzed samples. No correlation is found between TVC and E. coli amounts, indicating that E. coli are not always present as a component of bacterial load, even when total bacterial numbers were high for a given sample. This would suggest that the observed total bacterial may have originated from environmental sources, such as soil/organic debris, and not from direct fecal contamination. However, some samples showed $E$. coli counts more than $100 \mathrm{CFU} / 100 \mathrm{~mL}$, indicating severe contamination. High variation in E. coli could be due to the presence of varying amounts of organic content or clayey nature of the sediments or longer residence times of the groundwater, which can be envisaged from the highly heterogeneous nature of sediments in this region as mentioned in the geology of the region (section 2). It has been reported by several researchers that bacteria, especially fecal indicator bacteria, attach to finer particles in the aquifer and could lead to bacterial contamination (Pronk et al. 2007). Organic matter and other nutrients $\left(\mathrm{NH}_{4}{ }^{+}, \mathrm{NO}_{3}{ }^{-}\right.$and $\mathrm{PO}_{4}{ }^{3-}$ ) present in water can act as potential energy source for bacterial growth. Dissolved organic matter in water has also been considered as energy source for bacteria. Clark et al. (2003) also suggest that the high organic content and the clayey nature of sediments favor bacterial growth. Despite the low fecal contamination observed, continuous consumption of contaminated water may pose serious health risks, such as urinary tract infections, pulmonary infections, abscesses and skinwound infections, to local residents of this areas, especially children.

The production and proliferation of microbes depend on the favorable conditions prevailing in the nearby surroundings, e.g., the presence of dissolved oxygen (Jansons et al. 1989), water physicochemical characteristics such as $\mathrm{pH}$, temperature, salt content and organic carbon contents (Katzenelson 1978), and water source (Melnick and Gerba 1980). In the present case, effects of DO and TOC on bacterial contents were evaluated. E. coli and SRB amounts were plotted against corresponding DO levels. It can be seen from Fig. 5 that, in general, E. coli show an increasing trend with DO whereas SRB do not show any particular trend with DO. SRB do not degrade polysaccharides, proteins or lipids, but depend on the activity of fermentative bacteria for the supply of energy sources. A number of complex organic carbon sources have been considered as energy sources for biological sulphate reduction, such as, organic effluents (Boshoff et al. 2004), micro-algal biomass (Nedergaard et al. 2002). Therefore, it is possible that the SRB trends are impacted either by the presence of fermentative bacteria or by the availability of energy sources or by combined factors.

One deep well sample showing high DO with presence of SRB might be due to vertical leakage in the well. E. coli were also found to be present in low DO groundwater, which indicates that they are anaerobic or microaerophilic in nature. This condition of low dissolved oxygen can considerably extend the survival of these microorganisms in water, which can act as potential reservoirs for pathogens of fecal origin (Roslev et al. 2004). 


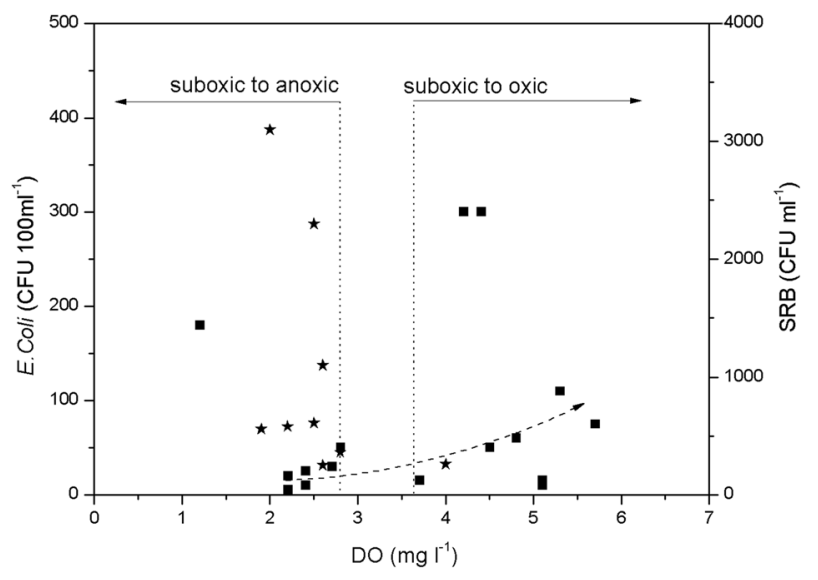

Fig. 5 Scatter plot of DO versus E. coli and SRB. The dashed arrow is a trend line to E. coli data

The E. coli show a positive correlation with TOC, whereas SRB do not show any particular trend, they are mostly present in samples with low TOC and are also spatially variable (Fig. 6). Association of coliform contaminants with organic matter was also noted by other researchers (Percival et al. 2000). In general, it is observed that the diversity and numbers of microorganisms diminish with depth from the surface of the soil to the rock strata below the aquifer. This is because, with increasing depth, the environment becomes increasingly hostile for life (Bitton and Harvey 1992). A decreasing trend was seen in the case of $E$. coli with well depth, whereas no such trend was observed in the case of SRB (Fig. 7).

The geochemical environment of the aquifer can be assessed by parameters like redox potential and dissolved oxygen; however, these parameters may be affected by sampling errors due to exposure to the atmosphere leading to erroneous numbers. Bacterial sulphate reduction is one of the most important respiration processes in anoxic habitats; therefore, the presence of SRB can be considered as a tool to indicate the redox state of the aquifer (Muna et al. 2007). Reducing bacteria, such as SRB, has been used very commonly by researchers to understand

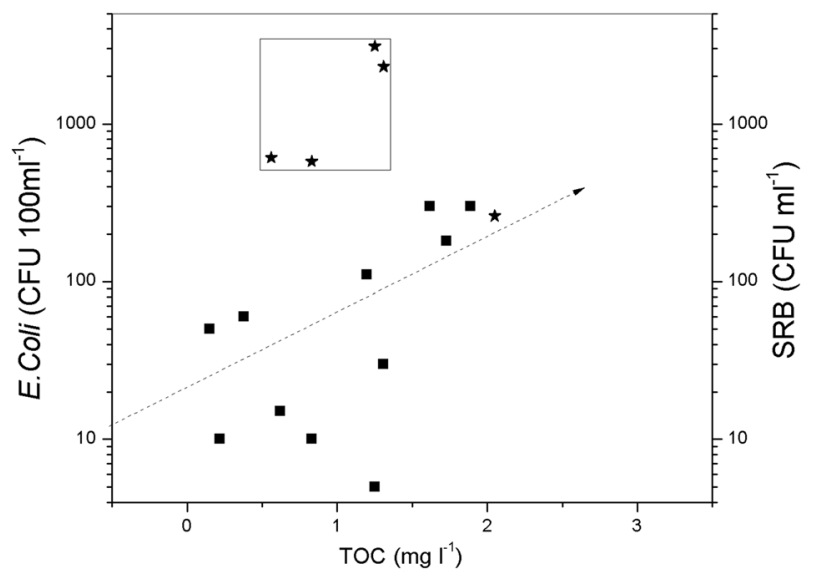

Fig. 6 Scatter plot of TOC versus E. coli and SRB. The box indicates the cluster of SRB data and the dashed arrow is a trend line to $E$. coli data 


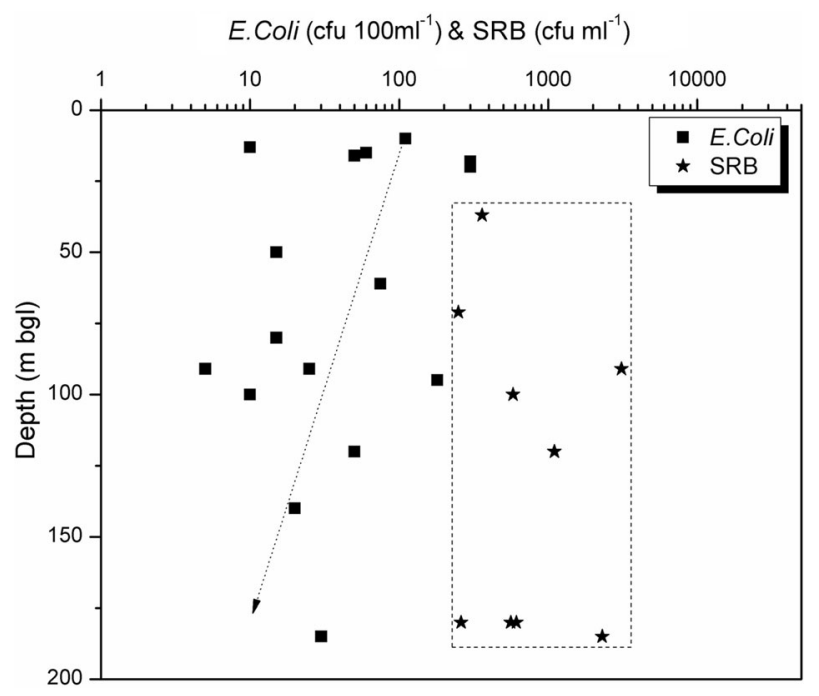

Fig. 7 Depth profiles of E. coli and SRB. The box indicates the cluster of SRB data, and the dotted arrow is a trend line to E. coli data

the fate of toxic metals and long lived radio nuclei in deep geological strata (Lotta and Karsten 2008). Presence of marcasite, which is a polymorph of pyrite, and reducing conditions in the deeper horizons of this coastal aquifer render the groundwater system vulnerable to arsenic contamination. However, it has also been reported that SRB can act as decontaminant by precipitating the dissolved metals as metal sulphides, or by incorporating the toxic metals into sulphide minerals, or by adsorption onto mineral surfaces (O’Day et al. 1998). For example, it is found that the SRB-produced iron sulphide had a considerably higher specific uptake capacity for different metal ions from solution than other adsorbents, such as activated carbon (Watson et al. 1995). Under anaerobic conditions, SRB can transform sulphate to hydrogen sulphide using simple organic substrates that can have importance in bioremediation of pollutants. Based on this, SRB use in water purification has now been commercialized (Chang et al. 2000). Assessment of reducing bacteria is also of great significance for abatement of metal pollution caused naturally or by manmade activities like mining, effluent discharge etc. This region being industrially well developed renders surface water bodies vulnerable by dumping high loads of toxic compounds, which subsequently infiltrates and pollute the groundwater. In addition, increase in sea-level also has a direct bearing on submarine groundwater discharge (SGD) dynamics and can strongly disturb the natural SGD flows, and hence, the proportion of nutrients and organic matter loadings going into the sea. This imbalance can further exacerbate the microbial pollution in groundwater (Paytan et al. 2004). All these observations and inferences obtained from this study stress the need to conduct investigations on quantification of SGD and its nutrient and organic matter loads to elucidate the responses of this coastal Pondicherry groundwater system to both natural and anthropogenic perturbations.

\section{Conclusions}

Compared to the surface water systems, the groundwater aquifer systems received less attention from an ecological point of view. Similar to surface water, the groundwater aquifer 
systems are highly vulnerable to both climate change and anthropogenic influences. Indiscriminate management of agricultural and industrial effluents increases the vertical percolation of chemical contaminants and organic matter to the deep aquifers. This study attempted to describe the microbial pollution in relation to other chemical properties of groundwater from the coastal Pondicherry region, India. The study indicates that the groundwater being used for potable purposes contains a wide variety of micro-organisms with loads varying from $1.8 \times 10^{3}$ to $3.3 \times 10^{4} \mathrm{CFU} / 100 \mathrm{~mL}$ in various aquifers. Even though all the microbes do not fall under fecal origin, half of the samples analyzed indicated presence of $E$. coli which is of fecal origin. E. coli showed positive correlations with DO and TOC while an inverse trend was noticed with the well depth. Sulphate reducing bacteria were found in few locations of deeper Tertiary and Cretaceous formations and DO levels were found to be very low. Presence of SRB is indicative of reducing condition of groundwater in the aquifer. Unlike E. coli, SRB do not show any systematic trend with DO, TOC and well depth. This study stresses the need for microbial evaluation of groundwater which can provide crucial information on the suitability for drinking source identification of fecal contamination and most importantly the redox condition of the aquifer. The possibility of in situ trace metal decontamination by selective reducing bacteria can also be inferred from this kind of study.

Acknowledgments Authors wish to thank Dr. Gursharan Singh, Former Associate Director (I), RC\&I Group, Bhabha Atomic Research Centre, Mumbai for his keen interest in this work. Dr. R. Shashidhar, Food Technology Division and Mrs. Ayushi, Analytical Chemistry Division are sincerely acknowledged for their help in microbial assay and TOC analysis, respectively. Thanks are also due to Dr. A.V.R. Reddy, Dr. S.D. Kumar of Analytical Chemistry Division and Dr. J.R. Bandekar of Food Technology Division of B.A.R.C., for their support and encouragement during the course of this study.

\section{References}

Anderson Y, Bohan P (2001) Disease surveillance and water borne outbreaks. In: Fewtrell L, Bartram J (eds) Water quality. Guidelines, standards and health. IWA Publishing, London, pp 11-133

BIS (1995) Bureau of Indian standards, Indian standard-drinking water-specification, First revision, second reprint, New Delhi

Bitton G, Harvey RW (1992) Transport of pathogens though soil and aquifers. In: Mitchell R (ed) Environmental microbiology. Wiley-Liss, New York, pp 103-124

Boshoff G, Duncan J, Rose PD (2004) The use of micro-algal biomass as a carbon source for biological sulphate reducing systems. Water Res 38:2659-2666

Cairneross S, Carruthers I, Curtis D, Feachem R, Bradley D, Baldwin G (1980) Evaluation for village water supply planning. Wiley, Chichester, pp. 277

CGWB (1993) Groundwater resources and development prospects in Pondicherry region union. Territory of Pondicherry, Central Ground Water Board, Ministry of Water Resources, Southern Region, Hyderabad

Chang IS, Shin PK, Kim BH (2000) Biological treatment of acid mine drainage under sulphate-reducing conditions with solid waste materials as substrate. Water Res 34:1269-1277

Church JA (2001) How fast are sea levels rising? Science 294:802-803

Clark A, Turner T, Padma D, Goutham K, Kalavati J, Bettaiya R (2003) Health hazards due to pollution of waters along the coast of Visakhapatnam, east coast of India. Ecotoxicol Environ Saf 56:390-397

Craun GF, Berger PS, Calderon RL (1997) Coliform bacteria and water borne disease outbreaks. J Am Water Works Assoc 89:96-104

D'ozouville N, Violette S, Gassama N, Dia A, Jendrzejewski N (2006) Origin and modelling of water salinization in a coastal aquifer of the Bay of Bengal: the kaluvelly watershed, Tamil Nadu, India. Bull Soc Geol Fr 177:333-345

Fifield FW, Haines PJ (2000) Environmental analytical chemistry, 2nd edn. Blackwell, Oxford

Foley JA, DeFries R, Asner GP, Barford C, Bonan G, Carpenter SR, Chapin FS, Coe MT, Daily GC, Gibbs HK, Helkowski JH, Holloway T, Howard EA, Kucharik CJ, Monfreda C, Patz JA, Prentice C, Ramankutty N, Snyder PK (2005) Global consequences of land use. Science 309:570-574 
Gilles B (2005) Towards a sustainable water resources management for Auroville and the Bioregion. In: Proceedings of UNESCO International Seminar, Auroville Centre for Scientific Research. Tamil Nadu. India. pp. $15-23$

Grabow WOK (1996) Waterborne diseases: update on water quality assessment and control. Water SA 22:193-202

Han W, Meehl GA, Rajagopalan B, Fasullo JT, Hu A, Lin J, Large WG, Wang J-W, Quan X-W, Trenary LL, Wallcraft A, Shinoda T, Yeager S (2010) Patterns of Indian ocean sea-level change in a warming climate. Nat Geosci 3:546-550

Hesham MB, El-Kordya MA, Hassan AE (2009) Contaminant transport in groundwater in the presence of colloids and bacteria: model development and verification. J Contam Hydrol 108:152-167

Hodegkiss IJ (1988) Bacteriological monitoring of Hong Kong marine water quality. Environ Int 14:495-499

Jansons J, Edmunds LW, Speight B, Bucens MR (1989) Survival of viruses in groundwater. Water Res 23:301306

Katzenelson E (1978) Survival of viruses. In: Berg G (ed) Indicator of viruses in water and food. Ann Arbor Science, Ann Arbor, pp 39-55

Kennedy WJ, Henderson RA (1992) Upper Maastrichtian ammonites (Phylloceratina, Lytoceratina, Ammonitina) from Pondicherry, South India. Palaeontol 35:381-442

Kirsten SH, Donald EC (1997) Sulphur isotope fractionation during bacterial sulphate reduction in organic-rich sediments. Geochim Cosmochim Acta 61:5351-5361

Kistemann T, Claben T, Koch C, Dangendorf F, Fischeder R, Gebel J, VacataV EM (2002) Microbial load of drinking water reservoir tributaries during extreme rainfall and runoff. Appl Environ Microbiol 68:21882197

Kumar AVK, Dube HC (1985) Occurrence and distribution of bacterial indicators of fecal pollution in the tidal waters of a muddy coast. J Mar Biol Assoc India 37:98-101

Lotta H, Karsten P (2008) Characterization of microbial processes in deep aquifers of the Fennoscandian Shield. Appl Geochem 23:1796-1819

Melnick JL, Gerba CP (1980) The ecology of the enteroviruses in natural waters. CRC Crit Rev Environ Control $10: 65$

Ministry of Health (1939) The bacteriological examination of water supplies, 2nd ed, Report on Public Health. Med. Subject London no. 71

Mohamed LM, Sonja SP (2008) Bacterial interactions with uranium: an environmental perspective. J Contam Hydrol 102:285-295

Mohan DC, Shantha NC, Kutty AT, Lokbharathi PA (2000) Pollution monitoring of coastal and estuarine areas: bacterial indicators along the south Gujarat coast. Ind J Mar Sci 29:43-47

Muna M, Rainer UM, Willibald S, Florian E (2007) Stable isotope fractionation during bacterial sulphate reduction is controlled by reoxidation of intermediates. Geochim Cosmochim Acta 71:4161-4171

Nedergaard RI, Risgaard-Peterson N, Finster K (2002) The importance of sulphate reduction associated with Ulva lactuca thalli during decomposition: a mesocosm experiment. J Exp Mar Biol Ecol 275:15-29

O’Day PA, Carroll SA, Waychunas GA (1998) Rock-water interactions controlling zinc, cadmium, and lead concentrations in surface waters and sediments, U.S. Tri-State Mining District. 1. Molecular identification using X-ray absorption spectroscopy. Environ Sci Technol 32:943-955

Okpokwasili GC, Akujobi TC (1996) Bacteriological indicators of tropical water quality. Environ Tax Water Qual Int J 11:77-81

Paruch A, Mahlum T, Robertson L (2014) Changes in microbial quality of irrigation water under different weather conditions in southeast Norway. Environ Process. doi:10.1007/s40710-014-0054-2

Pathak SP, Gopal K (2001) Rapid detection of Escherichia coli as an indicator of fecal pollution in water. Indian J Microbiol 41:139-151

Pathak SP, Mathur N, Dev B (1991) Effect of socio biological activities on microbial contamination of river water in different reasons. Environ Pollut Resour Lan Water 245-254

Paytan A, Boehm AB, Shellenbarger GG (2004) Bacterial contamination and submarine groundwater dischargea possible link. Environ Chem 1:1-2

Percival SL, Walker JT, Hunter PR (2000) Microbiological aspects of biofilms and drinking water. CRC Press, Boca Raton

Pipes WO (1981) Bacterial indicators of pollution. CRC Press, Boca Raton, 242

Planning Commission (2002) Report of the screening committee on drinking water supply \& sanitation (Rural and Urban) for tenth five year plan. New Delhi, India

Pronk M, Goldscheider N, Zopfi J (2007) Particle-size distribution as indicator for fecal bacteria contamination of drinking water from karst springs. Environ Sci Technol 41(24):8400-8405

Rahmstorf S (2007) A semi-empirical approach to projecting future sea level rise. Science 315(5810):368-370

NRC (National Research Council) (2000) Clean coastal waters: understanding and reducing the effects of nutrient pollution. The National Academies, Washington, D.C. 
Roslev P, Bjergbaek LA, Hesselsoe M (2004) Effect of oxygen on survival of fecal pollution indicators in drinking water. J Appl Microbiol 96:938-945

Scott TM, Salina P, Portier KM, Rose JB, Tamplin ML, Farrah SR, Koo A, Lukasik J (2003) Geographical variation in ribotype profiles of Escherichia coli isolates from human, swim, poultry, beef and dairy cattle in Florida. Appl Environ Microbiol 69:1089-1092

Seitzinger SP, Mayorga E, Bouwman AF, Kroeze C, Beusen AHW, Billen G, Van Drecht G, Dumont D, Fekete BM, Garnier J, Harrison A (2010) Global river nutrient export: a scenario analysis of past and future trends. Glob Biogeochem Cycles 24:GB0A08. doi:10.1029/2009GB003587

Shankar VPS, Kulkarni H, Krishnan S (2011) India's groundwater challenge and the way forward. EPW Econ Polit Wkly 42:37-45

Stein H, Kellermann C, Schmidt SI, Brielmann H, Steube C, Berkhoff SE, Fuchs A, Hahn HJ, Thulind B, Griebler C (2010) The potential use of fauna and bacteria as ecological indicators for the assessment of groundwater quality. J Environ Monit 12:242-254

Sukhija BS, Reddy DV, Vasanthakumar Reddy I (1987) Study of groundwater resources of Pondicherry and its environs. National Geophysical Research Institute, Hyderabad, pp. 1-153

Sundaram R, Henderson RA, Ayyasami K, Stilwell JD (2001) Alithostratigraphic revision and palaeoenvironmental assessment of the cretaceous system exposed in the onshore cauvery basin, southern India. Cretac Res 22:743-762

Thangarajan M, Thyagarajan G (2003) Situation study of groundwater vulnerability: a case study of Pondicherry, India. In: Malomo S, Wint SME (eds) Groundwater vulnerability in developing commonwealth countries. Commonwealth Secretariat, London, pp 22-46

Tranvik LJ (1992) Allochthonous dissolved organic matter as an energy source for pelagic bacteria and the concept of the microbial loop. Hydrobiology 229:107-114

Tyson RV, Pearson TH (1991) Modern and ancient continental shelf anoxia: an overview. In Modern and ancient continental shelf anoxia. Tyson RV and Pearson TH (eds.), Geol Soc Spec Publ 58: 1-26

Unnikrishnan AS, Shankar D (2007) Are sea-level-rise trends along the coasts of the north Indian ocean consistent with global estimates? Glob Planet Chang 57(3-4):301-307

Vaidya SY, Vala AK, Dube HC (2001) Bacterial indicators of fecal pollution and Bhavnagar coast. Indian J Microbiol 41:37-39

Venkateswaran K, Natarajan R (1987) Significance of bacterial indicators of pollution in the isolation of human pathogens in aquatic environment. Ind J Mar Sci 16:51-53

Vignesh S, Dahms HU, Kumarasamy P, Rajendran A, Kim BR, James RA (2015) Microbial effects on geochemical parameters in a tropical river basin. Environ Process. doi:10.1007/s40710-015-0058-6

Walsh JA (1990) Estimating the burden of illness of the tropics. In: Warren KS, Mahoud AAF (eds) Tropical and geographical medicines, 2nd edn. Mc-Graw Hill, New York

Watson JHP, Ellwood DC, Deng Q, Mikhalovsky S, Hayter CE, Evans J (1995) Heavy metal adsorption on bacterially produced FeS. Miner Eng 8:1097-1108

Westrich JT, Berner RA (1984) The role of sedimentary organic matter in bacterial sulphate reduction: the G model tested. Limnol Oceanogr 29:236-249

WHO (2004) Guidelines for drinking water quality recommendation. World Health Organization. Geneva. Recommendation 